\title{
GENETIC CHARACTERIZATION OF ISOLATES OF THE BASIDIOMYCETE AGARICUS BLAZEI BY RAPD
}

\author{
Nelson Barros Colauto ${ }^{1}$; Eustáquio Souza Dias ${ }^{2 *}$; Marcos Aparecido Gimenes ${ }^{3}$; Augusto Ferreira da Eira ${ }^{4}$ \\ ${ }^{1}$ Laboratório de Biologia Molecular, Universidade Paranaense, Umuarama, PR, Brasil; ${ }^{2}$ Departamento de Biologia, Universidade \\ Federal de Lavras, Lavras, MG, Brasil; ${ }^{3}$ Departamento de Genética, Universidade Estadual Paulista, Botucatu, SP, Brasil; \\ ${ }^{4}$ Departamento de Produção Vegetal, Faculdade de Ciências Agronômicas, Universidade Estadual Paulista, Botucatu, SP, Brasil.
}

Submitted: March 01, 2002; Approved: June 10, 2002

\section{SHORT COMMUNICATION}

\begin{abstract}
The genetic divergence of five isolates of Agaricus blazei was determined based on RAPD data. Results indicate that there is little genetic variability among the commercialized strains and that RAPD is a feasible and low cost technique that can be used to characterize this fungus.
\end{abstract}

Key words: Agaricus blazei, basidiomycete, genetic diversity, mushroom, RAPD.

Agaricus blazei Murrill (4), popularly known as the sun mushroom, God's mushroom, Piedade mushroom or simply medicinal mushroom, is of great interest because of its antimutagenic potential $(1,7,8)$. It occurs naturally in the hill regions of the Atlantic Rainforest in the south of São Paulo State, Brazil. According to mushroom growers, it was first collected by a local farmer and sent to Japan for identification, were substances with antitumor activity were identified $(3,6)$. The antitumor activity of these substances, tested in guinea pigs, arouse the interest of the Japanese market where the mushroom is known as "Himematsutake" (9). Because of the high demand of this mushroom in the Japanese market, some strains were returned to Brazil to be grown under natural conditions. Since then, Brazil has become the main grower and exporter of this mushroom to Japan. This preference happens because Brazil is the native country of this mushroom and has natural conditions for a low-cost cultivation.

Agaricus blazei has become an important alternative industry for small rural growers. Despite that, little is known about these mushroom strains. One of the main investigations is related to the genetic variability of commercialized isolates in the form of spawn (inocula) for mushroom growers. There are companies that commercialize spawn of Agaricus blazei claiming that they hold the primitive strain studied in Japan. Other companies claim that their spawn derive from the primitive one from Piedade region, the natural habitat of this mushroom. Nevertheless, independently of its primary origin, it is believed that most commercialized spawns show a strong genetic similarity. Thus, it is extremely important that these isolates be characterized with respect to their genetic divergence, so that it is possible to carry on studies to improve current strains or discover new strains of this mushroom.

One of the tools for the study of genetic divergence between different isolates is the RAPD technique which allows the detection of polymorphisms in rapid, direct, consistent and lowcost manner. The aim of the present study was to utilize the RAPD method to characterize different isolates of Agaricus blazei.

The strains utilized in this study were obtained from mushroom growers in São Paulo and Rio Grande do Sul States. They were maintained in the mycology repository of the Mushroom Section, Department of Vegetal Production, School of Agricultural Sciences, Universidade Estadual Paulista

\footnotetext{
* Corresponding author. Mailing address: Departamento de Biologia, Universidade Federal de Lavras, Caixa Postal 37 - Campus. $37200-000$, LavrasMG. Fax: (+5535) 3829-1341. E-mail: esdias@ufla.br
} 
(UNESP) in Botucatu-SP and in the Molecular Biology Laboratory, Universidade Paranaense (UNIPAR) in Umuarama$\mathrm{PR}$, in tubes with compost-agar and malt-agar medium at $20^{\circ} \mathrm{C}$. The strains were labeled as ABL (Agaricus blazei), followed by two digits referring to the year of collection and two digits referring to the number given to the isolate. The isolates are ABL 97/11, ABL 99/25, ABL 99/26, ABL 99/28 and ABL 99/29.

The fungi were cultivated in malt-agar medium for DNA extraction. Samples were transferred to $1.5-\mathrm{ml}$ microtubes for maceration with liquid nitrogen. The extraction method was described by Ferreira and Grattapaglia, 1995 (2). RAPD analysis was performed as described by Williams et al., 1990 (11). Twenty 10-base primers from a kit obtained from Operon Technologies were utilized for the polymorphism study. The resulting polymorphic differences were analyzed using the program TREECON for Windows $1.3 \mathrm{~b}$ by estimating the distance of 5 strains using the Link's coefficient and inferring the topology of the tree by the method of Clustering UPGMA.

From the 20 primers utilized, only 8 showed polymorphic bands, generating a total of 69 polymorphic bands, utilized for the analysis of the results. Three primers did not amplify probably due to a lack of homology and 9 showed monomorphic bands (Table 1). No polymorphism was observed between the isolates ABL 97/11 (from São Paulo-SP, Vitagaricus), 99/25 (from Araçatuba-SP, grower) and 99/29 (from Porto Alegre-RS, grower) indicating that they had probably the same origin, probably Japan (Fig. 1). Studies with other filamentous fungi have shown that isolates obtained in the same region or in regions of close proximity tend to show little genetic divergence $(5,10)$.

On the other hand, the isolates ABL 99/26 (from São José dos Campos-SP, reisolated from Jun17-Japan) and 99/28 (from Botucatu-SP, UNESP/FCA) showed variability both between themselves and when compared to the first group (Fig. 1). Besides the first group being of different origin, it is possible that these two isolates are the result of processes of genetic recombination and/or mutations. Considering that many growers use the open-air cultivation system for these mushrooms, it is possible that these processes occur naturally, generating genetic variability. The genetic differences demonstrated by RAPD analysis can be confirmed in relation to the classical morphological analysis of the basidiocarp between the strains ABL 99/29 and 99/26, which shows distinct morphological differences despite maintaining the characteristic pattern of the species (Colauto, personal communication).

These results show that some commercialized A. blazei spawns in Brazil have identical genotypes and are therefore probably clones, and there is little genetic variability among some commercialized strains. Additional studies with a larger number of primers and new isolates may thus provide promising material for the selection of new strains of $A$. blazei.
Table 1. Relationship among primers utilized and results obtained by RAPD analysis of Agaricus blazei isolates.

\begin{tabular}{ccc}
\hline Primers OP & Sequence & Polymorphism \\
\hline A02 & 5' TGCCGAGCTG & $\mathbf{X}$ \\
A16 & AGCCAGCGAA & - \\
A18 & AGGTGACCGT & + \\
B10 & CTGCTGGGAC & - \\
J02 & CCCGTTGGGA & $\mathbf{X}$ \\
J03 & TCTCCGCTTG & - \\
J04 & CCGAACACGG & - \\
J05 & CTCCATGGGG & + \\
K12 & TGGCCCTCAC & - \\
N02 & ACCAGGGGCA & + \\
P02 & TCGGCACGCA & - \\
P04 & GTGTCTCAGG & + \\
X04 & CCGCTACCGA & + \\
W02 & ACCCCGCCAA & + \\
W06 & AGGCCCGATG & - \\
W13 & CACAGCGACA & + \\
W18 & TTCAGGGCAC & - \\
Y01 & GTGGCATCTC & - \\
Y17 & GACGTGGTGA & $\mathbf{X}$ \\
Y20 & AGCCGTGGAA & + \\
\hline
\end{tabular}

Symbols: + With polymorphism; - Without polymorphism; X without amplification.

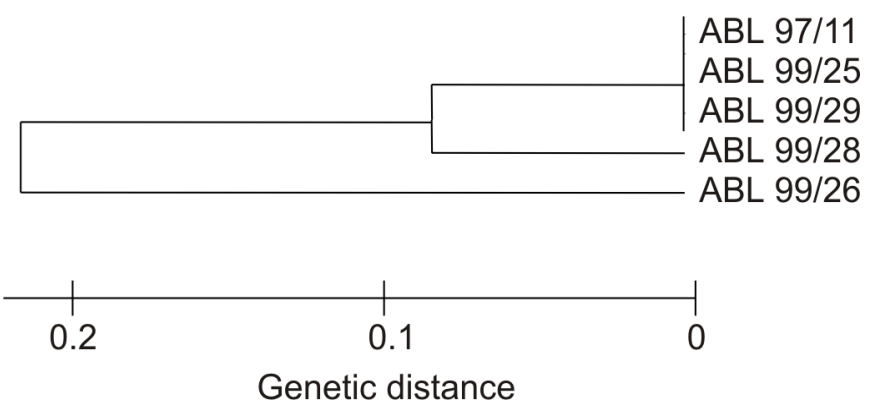

Figure 1. Dendrogram showing relative genetic distances between five Agaricus blazei isolates. The dendrogram was produced using similarity coefficients obtained from 69 polymorphic bands.

Such an approach will assist the genetic improvement of characteristics like productivity, production uniformity, size, coloration, shape and quantity of active principle in the mushroom. 


\section{ACKNOWLEGDEMENTS}

The authors thank FAPESP for financial support.

\section{RESUMO}

\section{Caracterização genética de isolados de Agaricus blazei por RAPD}

Determinou-se a divergência genética entre cinco isolados do fungo Agaricus blazei pela técnica de RAPD. Dos cinco isolados três não apresentaram qualquer divergência, sendo caracterizados como isolados de uma mesma origem, embora obtidos em locais diferentes do país. Outros dois isolados mostraram-se diferentes do primeiro grupo e divergentes entre si.

Palavras-chave: Agaricus blazei, basidiomiceto, cogumelo, diversidade genética, RAPD.

\section{REFERENCES}

1. Delmanto, R.D.; Alves de Lima, P.L.; Sugui, M.M.; Eira, A.F.; Salvatori, D.M.F.; Speit, G.; Ribeiro, L.R. Antimutagenic effect of Agaricus blazei Murrill mushroom on the genotoxicity induced by cyclophosphamide. Mutation Research, 496: 15-21, 2001.
2. Ferreira, M.E.; Grattapaglia, D. Introdução ao uso de marcadores moleculares em análise genética. Brasília: EMBRAPA, 1996. $220 \mathrm{p}$.

3. Fujimiya, Y.; Suzuki, Y.; Katakura, R.; Ebina, T. Tumor-specific cytocidal and immunopotentiating effects of relatively low molecular weight products derived from the basidiomycete, Agaricus blazei Murill. Anticancer Research, 19 (1A): 113-118, 1999.

4. Heinemann, P. Agarici Austroamericani. VIII. Agariceae des regions intertropicales d'Amérique du Sud. Bull. Jard. Bot. Nat. Belg., 62: 355-384, 1993

5. Junghans, D.T.; Gomes, E.A.; Guimarães, W.V.; Barros, E.G.; Araújo, E.F.A. Genetic diversity of the ectomycorrizal fungus Pisolithus tinctorius based on RAPD-PCR analysis. Mycorriza, 7: 243-248, 1998.

6. Kawagishi, H.; Inagaki, R.; Kanao, T.; Mizuno, T. Fractionation and antitumor activity of the water-insoluble residue of Agaricus blazei fruiting bodies. Carbohydrate Research, 186: 267-273, 1989.

7. Menoli, R.C.R.N.; Mantovani, M.S.; Ribeiro, L.R.; Speit, G.; Jordão, B.Q. Antimutagenic effect of the mushroom Agaricus blazei Murrill extracts on V79 cells. Mutation Research, 496: 5-13, 2001.

8. Mizuno, T. Kawariharatake, Agaricus blazei: medicinal and dietary effects. Food Reviews International, 11: 167-172, 1995.

9. Mizuno, T.; Hagiwara, T.; Nakamura, T. Antitumor activity and some properties of water-soluble polysaccharides from "Himematsutake", the fruiting body of Agaricus blazei Murill. Agricultural Biological Chemistry., 54: 2889-2896, 1990.

10. Silva, W.P.K.; Multani, D.S.; Deverall, B.J.; Lyon, B.R. RFLP and RAPD analyses in the identification and differentiation of isolates of the Leaf Spot fungus Corynespora cassiicola. Australian Journal of Botany, 43: 609-618, 1995.

11. Williams, J.G.; Kubelik, A.R.; Livak, K.J.; Rafalski, L.A.; Tingey, S.V. DNA polymorphism amplified by arbitrary primers are useful as genetic markers. Nucleic Acids Research., 18: 6531-6535, 1990. 